\title{
The Global Crisis And Crime: A Look Into Manufacturing Firms
}

https://doi.org/10.21272/sec.4(3).66-76.2020

Halil D. Kaya, ORCID: https://orcid.org/0000-0002-7535-9857

$\mathrm{PhD}$, Professor of Finance, Department of Accounting and Finance, College of Business and Technology, Northeastern State University, USA

Nancy L. Lumpkin-Sowers, ORCID: https://orcid.org/0000-0001-8356-1206

Associate Professor of Finance, Berea College, Berea, USA

\begin{abstract}
In this study, we examine how the 2007-2009 Global Crisis affected manufacturing firms' security spending and losses due to property crime (i.e. theft, robbery, vandalism, and arson) in Eastern Europe and Central Asia. Although we are currently experiencing a new global crisis due to the coronavirus, we cannot examine this current period yet since the current crisis is still ongoing. This article pulls together different literatures on the aftermath of the 2007-2009 Global Crisis in middle income economies, the influence of crisis on global supply chains, and the connections between unemployment and crime, to provide an empirical investigation of the trends in security spending within manufacturing firms across time. We find that fewer firms paid for security after the crisis has passed. On the other hand, the firms that spent money on security after the crisis ended actually spent a larger proportion of their sales on security. Our results indicate that, after the crisis, although fewer firms experienced losses due to crime, certain types of firms changed their spending on security. More of the smallest and largest firms, fewer of the firms with no female owner and fewer of the firms with a male top manager spent money on security after the crisis. Also, the firms with one or more female owner or a male top manager spent more money on security after the crisis. Overall, we find that there is a "gender effect" on security spending. Male and female owners' spending patterns are different. Also, male and female top managers' spending patterns are different. Also, our results show that manufacturing firms viewed crime as a much lower obstacle in the business environment after the financial crisis, and most firmtypes reported lower losses due to crime after the financial crisis had passed. We are hoping that these findings will guide manufacturing firms with respect to their operational spending. Although an economic crisis may cause crime rates to go up initially, over time, this trend reverses. Therefore, firms may want to recognize this cycle in responding to the next crisis.
\end{abstract}

Keywords: crime, manufacturing, Global Crisis, financial crisis.

JEL Classification: G01, K42, L60.

\section{(4)}

This work is licensed under a Creative Commons Attribution 4.0 International License.

Cite as: Kaya, H.D., Lumpkin-Sowers, N.L. (2020). The Global Crisis And Crime: A Look Into Manufacturing Firms. SocioEconomic Challenges, 4(3), 66-76. https://doi.org/10.21272/sec.4(3).66-76.2020.

(C) The Authors, 2020. This article is published with open access at Sumy State University.

\section{Introduction}

In this study, we explore firm-level effects originating from the 2007-2009 Global Financial Crisis, among manufacturing firms in Eastern Europe and Central Asia. Eastern Europe and Central Asia were perhaps among the later economies to be adversely affected by the financial crisis, because of less financial interdependence with the United States, but once international trade flows were impacted, it was very difficult to avoid the crisis, and its destabilizing effects. Understanding the many ways that firms are impacted by crises outside their control can help policymakers prepare effective public safety nets for the increased volatility we see in the world today, and help firms learn how to allocate their resources more effectively.

For firms, Global Crisis generally results in a rush to safety when the immediate effects of the crisis are felt. In the throes of the crisis, it is likely that firms will pull back on growth opportunities and on human capital investment because uncertainty rises. Businesses, worried about future demand, are unwilling to commit to 
investment activities, especially ones that don't increase the customer base. At the same time, unemployment conditions in the wider macro economy may lead to increased property crime as economic inequality is exacerbated and social safety nets in middle-income countries prove inadequate for the increased market volatility (See: (Ravallion, Bailing out the World's Poorest 2009, Cho and Newhouse 2011, Smith and Swain 2010). Increased security spending may be one side-effect of the crisis required by a manufacturer to keep inventory and property safe, but because of its unanticipated nature, may be overlooked in the planning of efficient resource allocation.

The side effects of Global Crisis matter because market inefficiency results from the substitute resource allocation that takes place by manufacturers when social safety nets are not correctly calibrated to the economic profligacy of "so called" leader nations. This is a likely circumstance in the region for the focus of this study as governments deregulated business and sought ways to embrace capitalist markets with very complicated supply chain networks and outsourced labor supply requirements (Cattaneo, Gereffi and Staritz 2010). So, whereas increased demands for regulation in banking are the obvious outcome of a financial crisis, the demands for social safety nets to improve the standards of living in the wake of crisis may go unanswered in smaller middle income or emerging economies, leading to more property crime. The manufacturer is forced to step in, substituting private spending for limited public resources. Understanding the degree to which this happens is important for resource allocation discussions. The financial crisis beginning in 2007 is an apt case for understanding the costs and benefits of increased globalization especially for some of the countries in our sample still emerging from communist market mechanisms.

In this paper, we compare the spending for security among manufacturers before and after the global financial crisis for middle income countries in Eastern Europe and Central Asia (29 countries). Although we are currently experiencing a new global crisis due to the coronavirus, we cannot examine this current period yet since the current crisis is still ongoing. In other words, we cannot compare the corona-related crisis period to the post-crisis period yet.

In this current study, Mann-Whitney-Wilcoxon tests show more of the smallest and largest firms spent money on security after the Global Crisis. While more sole proprietorships and partnerships paid for security after the crisis, fewer shareholding firms did, but when firms did spend on security, they spent more of their sales on it after the crisis. Some of the security spending appears to be gender driven, because fewer of the firms with no female owner and fewer of the firms with a male top manager spent money on security after the crisis. Also, the firms with one or more female owner or a male top manager spent more money on security after the crisis. Fewer firms reported losses due to crime after the crisis, viewing crime, theft, and disorder as less of an obstacle after the crisis.

This suggests that not all manufacturing firms in our sample faced significant reallocation of resources towards security after the financial crisis. This was true especially for the mid-sized (i.e. firms with 20-99 employees) firms.

The paper proceeds as follows: Section 2 explores the previous literature on the connections between Global Crisis, property crime, and security spending in manufacturing firms within the geographic region of our sample. Section 3 describes the sample data we used in our examination for 29 countries in Eastern Europe and Central Asia and the survey from which the empirical results are drawn. Section 4 discusses our findings of statistically significant differences in security spending before and after the financial crisis using MannWhitney-Wilcoxon tests on the mean values. Finally, Section 5 concludes by analyzing the testable implications of this work and the directions for future study.

\section{Literature review}

Even though the financial crisis started in the United States and the United Kingdom in the last quarter of 2007, the contagion was strong enough to spread to other countries around the world over 2008 and even into 2009. The economic effects were wide ranging, impacting both developed and emerging economies in some very similar ways, with declines in output and employment, bubbles for housing prices, and financial distress for firms. By looking back at financial crises over the last 100 plus years, Reinhardt and Rogoff (2009) find that on average unemployment rises by $7 \%$ in an economic downturn after a banking scandal and that output falls by $9 \%$. The length of time for these impacts to move through the economy can last two years for the 
output and four years for the unemployment (p.466). For middle-income countries, much of the primary trends applied, especially the closer the ties to the European Union.

In Eastern Europe and Central Asia, specifically, output went down, unemployment increased, and the business environment saw a significant amount of restructuring (Naude et al.., 2019). For the crisis that began in 2007, housing prices rose not only in the US and UK, but also in Spain, Ireland and many of the Eastern European countries (Claussen et al., 2010). The international financial linkages between countries helped spread the problems, in particular, Arvai et al. (2009) argues that much of Eastern Europe was plagued by loans denominated in foreign currency and where these links were the strongest was where economies retracted, but the global value chain models employed across Eastern Europe and Central Asia meant that trade linkages and labor markets provided a mechanism for impact as well (Cattaneo, Gereffi and Staritz 2010, Smith and Swain 2010, Pavlínek 2015). One export within the European Union was indeed labor. The impacts of this crisis on Central Europe are reinforced where the labor market segment most impacted among active workers was youth (Cho and Newhouse 2011) or temporary workers (Sharma and Winkler 2017). The significance of financial crisis on a microeconomic level for countries adjusting very quickly in their development to internationalization may have highlighted what Smith and Swain (2010) call "economic vulnerabilities." Ravallion $(2001,2009)$ stresses the expectation that the Global Crisis will have different effects within the middle income countries and that the social safety nets in place for post-communist countries following the leads of their market neighbors were not such a priority for spending when the surge from the crisis flowed into the countries.

One point of difference across countries was the economic quarter between 2007 and 2009 when a country experienced the negative impacts. Claessen et al. (2010) show that different countries entered negative GDP growth in different quarters and they identify patterns in the macroeconomic factors present for the countries hit. GDP and current account imbalances were bigger in the countries first hit. The second group affected were countries closely connected to the US through international financial linkages, the more Western European countries and the Baltic States1. Eastern European, Asian, and emerging markets were impacted a bit later in quarters 3 and 4 of 2008 or quarter 1 of 2009 as international trade was ultimately impacted (Claessen et al., 2010, p. 278). One explanation is that firms, looking to protect what they already had, might be sensitive to the incentives created by less demand for the intermediate goods that dominated manufacturing in these countries and increased unemployment. Manufacturing firms were not investing at this point, but there is heightened anxiety to keep inventory and property safe. Under this view increased spending on security becomes a necessity for firms.

The literature on crisis, unemployment, and ultimately crime suggests a positive relationship. Fishback et al. (2010) emphasize that the importance of the social insurance programs in place during an economic downturn are vital for understanding criminal activity. Their focus of study, however, is the United States during the Great Depression. More recent consideration of the links between unemployment and crime shows an elastic response of crime to unemployment (Lin 2008). Russians interviewed before and after the 1998 financial crisis in Russia reported much lower levels of well-being (Lokshin and Ravallion 2000). The authors argue that the public response to deteriorating living standards was inadequate. Ivaschenko et al. (2012), also focusing on 1998 financial crisis in Russia, argues that real income, unemployment levels, and income inequality are the most important factors for explaining crime rates for countries in transition after communism. The costs of crime prevention get pushed to firms and individuals as the social safety net lags behind the economic climate.

There is only limited research on crime against firms in the region of our sample, but Amin (2010) does show that the firms in this region are spending a disproportionate amount of their revenues on security before the financial crisis. His focus is on crime in the Eastern Europe and Central Asia region for 2007, and he uses the 2008 Enterprise survey. Balas and Kaya (2019a, 2019b) consider the trends in security spending for the region before and after the global financial crisis for retailers and wholesalers, finding that wholesalers paid the same for security pre and post financial crisis, but that less retailers invested in security after the crisis. Interestingly, both groups of merchants viewed crime as less troublesome following the crisis. Naude et al. (2019) focus on Eastern and Central Europe and look at manufacturing over time, to see how the countries that joined the European Union by 2007 performed, and find significant, competitive restructuring during the crisis, but also

\footnotetext{
${ }^{1}$ The Baltic States include Estonia, Latvia, and Lithuania.
} 
a strong recovery for manufacturing in particular. Pavlinek (2015) analyzed the automobile industry in Czechia and Slovakia, finding some consolidation in the sector during the crisis but with few plant closures. Cattaneo et al. (2015), edit a collection that focuses on the role of developing countries within global value chains that continue to guide production after the financial crisis. Within this, researchers explore more specifically the apparel industry, which saw some shifts for Eastern Europe in the value chain by 2008, with Poland and Hungary shifting out, Romania and Turkey maintaining position, and Bulgaria shifting into production chains (Gereffi and Frederick 2010, p. 204). Understanding the challenges faced by firms in manufacturing across this region will help us understand the evolution of global value chains and the resilience of the production of intermediate goods to globalization.

To summarize, the previous literature shows that economic crises affect real income, unemployment levels and income inequality, and that these negative effects cause the crime rate to go up during this period. Generally, firms tend to view crime as less troublesome following the crisis. While some of the industry groups reduce their security spending after the crisis has passed, others keep their security spending flat. In this current study, for manufacturing firms, we go into detail and examine the characteristics of firms that reduce their security spending after the 2008-2009 Global economic crisis has passed.

\section{The sample and the survey}

In this study, we use the Business Environment and Enterprise Performance Survey (i.e. BEEPS) which is a joint initiative of the World Bank and the European Bank for Reconstruction and Development ${ }^{2}$. This survey was conducted in Eastern Europe and Central Asia (in 29 countries). To understand the influence of crime on security spending before and after the global financial crisis, we use the Enterprise Surveys from 2008 and 2013. These survey responses represent spending in 2007 for the pre-crisis response and 2012 for the postcrisis period. This time lag allows us to see the full impact of the crisis. Since we focus on manufacturing firms, we use the manufacturing questionnaire, rather than services questionnaire.

We are interested in manufacturing firms' security spending and their losses due to crime - which includes: theft, robbery, vandalism, and arson - pre- and post-crisis. Therefore, we are interested in the responses given to the following four questions:

Question 1: pay for security?

"In fiscal year 20XX, did this establishment pay for security, for example equipment, personnel, or professional security services?" Here, "yes" is coded as 1 and "no" is coded as 2.

Question 2: security spending was what $\%$ of sales?

"In fiscal year 20XX, what percent of this establishment's total annual sales was paid for security, or what was the total annual cost of security?" Here, the respondents tell us what percentage of their sales were spent on security.

\section{Question 3: did crime lead to loss?}

"In fiscal year 20XX, did this establishment experience losses as a result of theft, robbery, vandalism, or arson?" Here, "yes" is coded as 1 and "no" is coded as 2.

\section{Question 4: is crime an obstacle for the firm?}

"Are crime, theft, and disorder No Obstacle, a Minor Obstacle, a Moderate Obstacle, a Major Obstacle, or a Very Severe Obstacle to the current operations of this establishment?" Here, "no obstacle" is coded as 0, "minor obstacle" is coded as 1, "moderate obstacle" is coded as 2, "major obstacle" is coded as 3, and "very severe obstacle" is coded as 4 .

Table 1 (below) presents the summary statistics for answers to these four questions in our sample countries. On average, among manufacturing firms, less paid for security, but a greater percentage of sales was allocated to it, less experienced crime, and more firms did not see crime as an obstacle. Panel A provides the mean scores for QUESTION 1: PAY FOR SECURITY?, which changed from 1.40 in 2008 to 1.42 in 2013, indicating that more firms answered "no" to the question (which was coded as more 2s). Fewer firms spent

\footnotetext{
${ }^{2}$ The survey is more commonly referred to as the Enterprise Surveys.
} 
money on security. Interestingly, for those that answered yes to QUESTION \#1, a higher percentage of sales went to security after the financial crisis, as indicated by the mean of $4.07 \%$ in the survey for 2008 and $4.42 \%$ in 2013.

Table 1. Summary Statistics for Manufacturing Firms

\begin{tabular}{|c|c|c|c|c|c|c|}
\hline Survey Year & \multicolumn{3}{|c|}{2008} & \multicolumn{3}{|c|}{2013} \\
\hline & $\mathbf{N}$ & Mean & Std & $\mathrm{N}$ & Mean & Std \\
\hline \multicolumn{7}{|l|}{ Panel A. } \\
\hline Did the Firm. Pay for Security during Last Year? & 4,433 & 1.40 & 0.49 & 4,207 & 1.42 & 0.49 \\
\hline \multicolumn{7}{|l|}{ Panel B. } \\
\hline Percentage of Annual Sales Paid for Security? & 1,315 & 4.07 & 6.72 & 1,214 & 4.42 & 6.74 \\
\hline \multicolumn{7}{|l|}{ Panel C. } \\
\hline Loss due to Theft, Robbery, Vandalism, or Arson? & 4,427 & 1.85 & 0.36 & 4,208 & 1.90 & 0.30 \\
\hline \multicolumn{7}{|l|}{ Panel D. } \\
\hline Are Crime, Theft, and Disorder an Obstacle? & 4,243 & 1.25 & 1.42 & 4,172 & 0.47 & 0.94 \\
\hline
\end{tabular}

Note 1: In Panels A and C, "Yes" is 1, "No" is 2. Note 2: In Panel D, "No obs." is 0, "Minor" is 1, "Moderate" is 2, "Major" is 3, "Very Severe" is 4.

Source: Authors' own work.

Panel C summarizes answers to QUESTION \#3: DID CRIME LEAD TO LOSS?, where the mean score was 1.85 in the survey collected in 2008, and 1.90 in 2013. More firms answered no to this question, bringing the mean up a bit towards 2. Finally, panel D shows that while the mean score for QUESTION \#4: IS CRIME AN OBSTACLE FOR THE FIRM? was 1.25 in 2008, it was 0.47 in 2013. On average, firms' perception of crime as a constraint in the business environment was notably less, on average, post-crisis. Further, the average response in 2013 is below 1 , at .94, indicating that many respondents are answering "No Observations" to this question. It might be worth noting that the standard deviation of responses for the first 3 questions remains fairly consistent pre- and post-crisis. The answers in QUESTION \#4, however are much less spread out after the financial crisis. There appears to be a notable change here in the belief that crime is a real constraint to the business environment after the financial crisis. To examine what the survey can tell us about the types of firms - their size, their legal form of organization, the genders of their leadership, ISO certification holders - where crime is still an issue among manufacturers, we next consider the statistical significance in mean responses for different firm characteristics pre- and post-crisis for each of the four questions.

\section{Empirical results for firm characteristics and crime incidence}

The number of firms paying for security dropped in a statistically significant manner in this sample, but is this true for small, medium, and large firms? Table 2 shows the results of the responses given for QUESTION 1: PAY FOR SECURITY? once the sample has been adjusted for firm characteristics. The mean value responses in $2008(\mu=1.40)$ and $2013(\mu=1.42)$ are statistically significant, according to the Mann-Whitney-Wilcoxon test $(\mathrm{p}=0.0234)$. When we examine different firm size groups, where firm size is measured by number of employees, we find that more small firms (i.e. firms with five-to-nineteen employees) and large firms (i.e. firms with more than ninety-nine employees), paid for security after the financial crisis at a statistically significant level. For firms with five-to-nineteen employees, while the mean value is 1.52 pre-crisis, it is 1.49 post-crisis $(\mathrm{p}=0.0413)$. For firms with more than ninety-nine employees, while the mean value is 1.25 precrisis, it is 1.22 post-crisis ( $\mathrm{p}=0.0432$ ). The medium sized firms' (classified as 20-99 employees) response to payment for security stayed the same, and so did not show a statistically significant difference. More small and large firms paid for security after the crisis.

Table 2. Did the Manufacturer Pay for Security during Last Year?

\begin{tabular}{|l|c|c|c|}
\hline \multicolumn{2}{|c|}{ Wilcoxon Test } & $\mathbf{2 0 1 3}$ & $\mathrm{p}$-value \\
\hline & $\mathbf{2 0 0 8}$ & $\mathbf{2 0 1 3}$ & 0.0234 \\
\hline all & 1.40 & 1.42 & 0.0413 \\
\hline employees5-19 & 1.52 & 1.49 & 0.0413 \\
\hline employees20-99 & 1.39 & 1.39 & 0.4254 \\
\hline employees $>99$ & 1.25 & 1.22 & 0.0432 \\
\hline part of a larger firm & 1.27 & 1.28 & 0.4089 \\
\hline
\end{tabular}


Table 2 (cont.). Did the Manufacturer Pay for Security during Last Year?

\begin{tabular}{|l|c|c|c|}
\hline \multicolumn{1}{|c|}{ Wilcoxon Test } & $\mathbf{2 0 1 3}$ & $\mathbf{p}$-value \\
\hline & $\mathbf{2 0 0 8}$ & $\mathbf{2 0 1 3}$ & 0.0441 \\
\hline not part of a larger firm & 1.41 & 1.43 & 0.0021 \\
\hline shareholding firm trading in the stock market & 1.30 & 1.44 & 0.0003 \\
\hline shareholding firm shares traded privately & 1.37 & 1.41 & 0.4 \\
\hline sole proprietorship & 1.53 & 1.45 & 0.0079 \\
\hline partnership & 1.56 & 1.32 & 0.0032 \\
\hline limited partnership & 1.47 & 1.47 & 0.4887 \\
\hline other & 1.47 & 1.46 & 0.4618 \\
\hline one or more female owner & 1.39 & 1.38 & 0.3970 \\
\hline no female owner & 1.41 & 1.44 & 0.0093 \\
\hline top manager female & 1.40 & 1.40 & 0.4739 \\
\hline top manager not female & 1.39 & 1.42 & 0.0112 \\
\hline firm without an intl recog. quality certification & 1.44 & 1.45 & 0.2271 \\
\hline firm with an intl recog. quality certification & 1.30 & 1.34 & 0.0099 \\
\hline
\end{tabular}

Note: Yes is 1 , No is 2 .

Source: Authors' own work.

When we differentiate among firms based on whether they are a part of a larger firm or not part of a larger firm, we are seeing that fewer firms that are not part of a larger firm paid for security after the crisis. For this group of firms, while the mean value is 1.41 pre-crisis, it is 1.43 post-crisis $(\mathrm{p}=0.0441)$. We do not see a significant change for the firms that are part of a larger firm. For this group, the mean value is 1.27 pre-crisis while it is 1.28 post-crisis $(\mathrm{p}=0.4089)$.

All categories of legal ownership, except limited partnership and other, showed statistically significant differences in survey response before and after the crisis. Another way to examine these firms is from the perspective of legal ownership status (shareholding firm with shares trading in the market, shareholding firm with shares traded privately, sole proprietorship, partnership, etc.). While fewer shareholding firms spent money on security, more sole proprietorships and partnerships paid for security after the crisis. For shareholding firms with shares traded in the market, while the mean value is 1.30 pre-crisis, it is 1.44 postcrisis $(\mathrm{p}=0.0021)$. For shareholding firms with shares traded privately, while the mean value is 1.37 pre-crisis, it is 1.41 post-crisis $(\mathrm{p}=0.0003)$. This indicates that fewer firms in these two groups spent money on security post-crisis when compared to pre-crisis. On the other hand, for sole proprietorships, while the mean value is 1.53 pre-crisis, it is 1.45 post-crisis $(\mathrm{p}=0.0079)$. For partnerships, while the mean value is 1.56 pre-crisis, it is 1.32 post-crisis $(\mathrm{p}=0.0032)$. This indicates that more firms in these two groups spent money on security postcrisis when compared to pre-crisis. This finding reinforces the small firm finding because sole proprietorships and partnerships are likely to have less employees per firm.

When the sample is evaluated from the perspective of gender and quality management perspectives, the results are not so clear with respect to the number of firms allocating resources to security. For gender, on the one hand, fewer firms with all male owners (i.e. "no female owner") spent money on security post-crisis when compared to pre-crisis. For this group of firms, while the mean value is 1.41 pre-crisis, it is 1.44 post-crisis $(\mathrm{p}=0.0093)$. On the other hand, we do not see a significant difference for firms with one or more female owners between pre- and post-crisis. Further, when a firm holds an ISO quality certification ${ }^{3}$ we are seeing that fewer firms paid for security after the crisis. For this group of firms, while the mean value is 1.30 pre-crisis, it is 1.34 post-crisis $(\mathrm{p}=0.0099)$. On the other hand, we do not see a statistically significant difference for firms without an internationally recognized quality certification. This result may be due to the firm-size effect that we have found earlier (fewer firms with more than ninety-nine employees spent money on security after the crisis and these firms were the ones holding an internationally recognized quality certification).

Table 3 shows that the responses given pre- and post- for QUESTION 2: SECURITY SPENDING WAS WHAT \% OF SALES? were statistically significantly different from the perspective of being part of a larger firm, legal ownership in limited partnerships, and in gender. In general, for all firms, the mean value of the

\footnotetext{
${ }^{3}$ For example, ISO 9000, 9002, 14000, etc. These are standards that denote Quality Management Systems (QMS), where a third party assessor has evaluated the firm's process for a particular standard, and documents a given level of quality for upstream suppliers and downstream customers.
} 
responses in 2008 is $4.07 \%$, while it is $4.42 \%$ in 2013 . The difference between the responses in the pre- and post-crisis periods is statistically significant $(\mathrm{p}=0.0363)$. For the firms that did spend resources on security, more money for security was allocated post-crisis. This finding is reinforced from the perspective of being part of a larger firm, where firms spent more on security post-crisis (at $5 \%$ level of confidence). For this group of firms, while the mean value is $3.63 \%$ pre-crisis, it is $4.70 \%$ post-crisis $(\mathrm{p}=0.0385)$. Firms that were not part of a larger firm also spent more on security post-crisis (at $10 \%$ level). For this group of firms, while the mean value is $4.13 \%$ pre-crisis, it is $4.39 \%$ post-crisis $(\mathrm{p}=0.0971)$.

Table 3. Percentage of Annual Sales Paid for Security

\begin{tabular}{|l|l|l|c|}
\hline \multicolumn{1}{|c|}{ Wilcoxon Test } & \multicolumn{2}{c|}{ p-value } \\
\hline & $\mathbf{2 0 0 8}$ & $\mathbf{2 0 1 3}$ & 0.0363 \\
\hline all & 4.07 & 4.42 & 0.3422 \\
\hline employees5-19 & 4.88 & 4.40 & 0.1429 \\
\hline employees20-99 & 3.87 & 4.76 & 0.3110 \\
\hline employees>99 & 3.61 & 3.60 & 0.0385 \\
\hline part of a larger firm & 3.63 & 4.70 & 0 \\
\hline not part of a larger firm & 4.13 & 4.39 & 0.0971 \\
\hline shareholding firm trading in the stock market & 4.19 & 5.12 & 0.1674 \\
\hline shareholding firm shares traded privately & 3.71 & 4.21 & 0.0038 \\
\hline sole proprietorship & 5.81 & 6.26 & 0.1603 \\
\hline partnership & 3.35 & 3.18 & 0.4687 \\
\hline limited partnership & 4.19 & 1.00 & 0.0310 \\
\hline other & 3.94 & 3.52 & 0.2687 \\
\hline one or more female owner & 3.72 & 4.56 & 0.0006 \\
\hline no female owner & 4.20 & 4.36 & 0.3026 \\
\hline top manager female & 4.41 & 4.44 & 0.4120 \\
\hline top manager not female & 4.02 & 4.41 & 0.0397 \\
\hline firm without an intl recog. quality certification & 4.41 & 4.67 & 0.0412 \\
\hline firm with an intl recog. quality certification & 3.56 & 3.98 & 0.3239 \\
\hline
\end{tabular}

Source: Authors' own work.

A notable result is that limited partnerships spent less on security while shareholding firms with privately traded shares spent more on security post-crisis. For limited partnerships, the mean value is $4.19 \%$ pre-crisis, but only $1.00 \%$ post-crisis $(\mathrm{p}=0.0310)$. This is a significant drop. For shareholding firms with privately traded shares, while the mean value is $3.71 \%$ pre-crisis, it is $4.21 \%$ post-crisis $(\mathrm{p}=0.0038)$. This is a significant increase. We do not see a significant change in security spending for the other types of firms (sole proprietorships, partnerships, etc.). More mixed results occur when we control for gender in leadership and proxy for quality management with an ISO certification. Firms with one or more female owners or a male top manager spent more on security post-crisis. For firms with one or more female owners the mean value is $3.72 \%$ pre-crisis, it is $4.56 \%$ post-crisis $(\mathrm{p}=0.0006)$. However, for firms with a male top manager, the mean value is $4.02 \%$ pre-crisis, it is $4.41 \%$ post-crisis $(\mathrm{p}=0.0397)$. We do not see a significant change in security spending for firms with no female owner or for firms with a female top manager. The results also show that firms without an internationally recognized quality certification spent more on security $(4.41 \%$ versus $4.67 \%$, $\mathrm{p}=0.0412$ ). But we do not see a significant change in security spending as a percentage of sales for firms with an international quality certification. Table 4 tabulates the firms' yes/no response to whether there were losses due to theft, robbery, vandalism, or arson pre- and post-crisis. Fewer firms experienced losses due to crime post-crisis when compared to 2008. The mean value is 1.85 in 2008 versus 1.90 in 2013 (p<0.0001). Looking into the subgroups, most show a statistically significant reduction in the reports of losses due to crime (except for a few legal status groups like sole proprietorships, limited partnerships, and other). Fewer firms are experiencing losses due to crime post-crisis, and the results are robust across almost all subgroups.

Table 4. Any Losses due to Theft, Robbery, Vandalism, or Arson?

\begin{tabular}{|l|c|c|c|}
\hline \multicolumn{2}{|c|}{ Wilcoxon Test } & $\mathbf{2 0 1 3}$ & $\mathbf{p}$-value \\
\hline & $\mathbf{2 0 0 8}$ & $\mathbf{2 0 1 3}$ & $<0.0001$ \\
\hline all & 1.85 & 1.90 & $<0.0001$ \\
\hline employees5-19 & 1.86 & 1.91 & 0.0001 \\
\hline employees20-99 & 1.85 & 1.90 & 0 \\
\hline employees $>99$ & 1.82 & 1.88 & 0.0003 \\
\hline part of a larger firm & 1.83 & 1.87 & 0.0367 \\
\hline
\end{tabular}


Table 4 (cont.). Any Losses due to Theft, Robbery, Vandalism, or Arson?

\begin{tabular}{|l|c|c|c|}
\hline \multicolumn{2}{|c|}{ Wilcoxon Test } & $\mathbf{2 0 1 3}$ & $\mathbf{p}$-value \\
\hline & $\mathbf{2 0 0 8}$ & $\mathbf{2}$ & $<0.0001$ \\
\hline not part of a larger firm & 1.85 & 1.90 & 0.0053 \\
\hline shareholding firm trading in the stock market & 1.80 & 1.91 & $<0.0001$ \\
\hline shareholding firm shares traded privately & 1.85 & 1.91 & 0.2686 \\
\hline sole proprietorship & 1.89 & 1.88 & 0.0663 \\
\hline partnership & 1.81 & 1.91 & 0.2200 \\
\hline limited partnership & 1.89 & 1.82 & 0.1340 \\
\hline other & 1.86 & 1.91 & 0.000 \\
\hline one or more female owner & 1.84 & 1.88 & 0 \\
\hline no female owner & 1.85 & 1.91 & $<0.0001$ \\
\hline top manager female & 1.87 & 1.90 & 0.0115 \\
\hline top manager not female & 1.84 & 1.90 & $<0.0001$ \\
\hline firm without an intl recog. quality certification & 1.85 & 1.91 & $<0.0001$ \\
\hline firm with an intl recog. quality certification & 1.84 & 1.89 & $<0.0001$ \\
\hline
\end{tabular}

Note: Yes is 1 , No is 2 .

Source: Authors' own work.

The final question of interest in the survey is QUESTION 4: IS CRIME AN OBSTACLE FOR THE FIRM?, and the responses show that firms in the sample region consistently perceive that crime is less of an obstacle in the business environment. Table 5 compares the responses across firm characteristics. The possible responses include, "Are crime, theft, and disorder: No Obstacle, a Minor Obstacle, a Moderate Obstacle, a Major Obstacle, or a Very Severe Obstacle to the current operations of this establishment?". Here, "no obstacle" is coded as 0 , "minor obstacle" is coded as 1, "moderate obstacle" is coded as 2, "major obstacle" is coded as 3 , and "very severe obstacle" is coded as 4 .

Table 5. Are Crime, Theft, and Disorder an Obstacle

\begin{tabular}{|l|c|c|c|}
\hline \multicolumn{2}{|c|}{ Wilcoxon Test } & $\mathbf{2 0}$ & $\mathbf{p}$-value \\
\hline & $\mathbf{2 0 0 8}$ & $\mathbf{2 0 1 3}$ & $<0.0001$ \\
\hline all & 1.25 & 0.47 & $<0.0001$ \\
\hline employees5-19 & 1.37 & 0.50 & $<0.0001$ \\
\hline employees20-99 & 1.24 & 0.44 & $<0.0001$ \\
\hline employees>99 & 1.12 & 0.39 & $<0.0001$ \\
\hline part of a larger firm & 1.07 & 0.55 & $<$ \\
\hline not part of a larger firm & 1.27 & 0.46 & $<0.0001$ \\
\hline shareholding firm trading in the stock market & 1.45 & 0.35 & $<0.0001$ \\
\hline shareholding firm shares traded privately & 1.13 & 0.46 & $<0.0001$ \\
\hline sole proprietorship & 1.52 & 0.57 & $<0.0001$ \\
\hline partnership & 1.41 & 0.41 & $<0.0001$ \\
\hline limited partnership & 1.15 & 0.41 & 0.0282 \\
\hline other & 1.67 & 0.35 & $<0.0001$ \\
\hline one or more female owner & 1.21 & 0.50 & $<0.0001$ \\
\hline no female owner & 1.28 & 0.45 & $<0.0001$ \\
\hline top manager female & 1.30 & 0.49 & $<0.0001$ \\
\hline top manager not female & 1.24 & 0.46 & $<0.0001$ \\
\hline firm without an intl recog. quality certification & 1.37 & 0.45 & $<0.0001$ \\
\hline firm with an intl recog. quality certification & 1.01 & 0.49 & $<0.0001$ \\
\hline
\end{tabular}

Note: "No obs." is 0, "Minor" is 1, "Moderate" is 2, "Major" is 3, "Very Severe" is 4.

Source: Authors' own work.

We are seeing that the firms saw crime, theft and disorder as less of an obstacle after the crisis. The mean value for all firms is 1.25 in 2008 , but by 2013 , the mean response dropped to 0.47 ( $\mathrm{p}<0.0001$ ). In other words, in the 2008 survey, the average respondent saw crime, theft and disorder as a "Minor" to "Moderate" obstacle for their business. In the 2013 survey, these issues were seen as almost no obstacle to the firms' operations. The table shows that this finding is valid for all firm sizes and firm types. 


\section{Conclusion}

In this study, we examine the impact of the 2007-2009 Global Crisis on manufacturing firms' security concerns and losses. A few of the results show a marked difference before and after the financial crisis. Fewer firms paid for security after the crisis, but more small and large employers reported spending on security after the financial crisis. If we focus on the percentage of sales spent on security, fewer shareholding firms spent money on security, but more sole proprietorships and partnerships paid for security after the crisis. When we examine the impact of gender among firm leadership, it is clear that male owners and male top managers were less concerned about security after the crisis.

Next, we examine the amount of money spent on security. We find that firms that spent money on security spent more after the crisis ( $4.42 \%$ versus $4.07 \%$ of sales). Limited partnerships spent less on security while shareholding firms with privately traded shares spent more on security after the crisis. Also, firms with one or more female owner or a male top manager spent more on security. Our results also show that firms without an internationally recognized quality certification spent more on security. These are the small firms. They are spending on security and the cost is a bigger proportion of their sales.

After focusing on security spending, we shift our attention to losses due to crime. We find that, after the crisis, fewer firms reported losses due to crime. This finding is valid for almost all types of firms regardless of firm size, firm type, etc. This is an interesting finding because earlier we found that certain types of firms changed their spending on security after the crisis, but as we are finding here, after the crisis, fewer firms had losses due to crime.

In the final section, we examine whether the respondents saw crime, theft and disorder as an obstacle. The results show that firms' perception of crime in the business environment was lower after the crisis than before. This finding is valid for all firm sizes and firm types. While before the crisis, the average respondent was seeing crime, theft and disorder as a "Minor" to "Moderate" obstacle for their business, after the crisis, these issues were seen as almost no obstacle. This finding suggests that the spending on security that occurred was viewed as productive by the firms, but may not have been required.

We are hoping that these findings will guide manufacturing firms with respect to their operational spending. After the crisis, overall, there was a sense of optimism regarding crime. This was supported by lower dollar losses due to crime during this period. While most firms realized that crime was less of an issue after the crisis ended and adjusted their security spending accordingly, certain types of firms (i.e. firms with five-to-nineteen employees, or firms with a female owner or a female top manager) had either not realized this trend (i.e. crime was subsiding) or were driven by safety concerns. We conclude that although an economic crisis may cause crime rates to go up initially, over time, this trend reverses. Therefore, firms may want to recognize this cycle in responding to the next crisis.

Funding: self-funded.

Author Contributions: conceptualization, Halil D. Kaya; data curation, Halil D. Kaya; formal analysis, Halil D. Kaya; funding acquisition, Halil D. Kaya; investigation, Halil D. Kaya and Nancy L. LumpkinSowers; methodology, Halil D. Kaya; project administration, Halil D. Kaya and Nancy L. Lumpkin-Sowers; resources, Halil D. Kaya and Nancy L. Lumpkin-Sowers; software, Halil D. Kaya; supervision, Halil D. Kaya; validation, Halil D. Kaya; visualization, Halil D. Kaya and Nancy L. Lumpkin-Sowers; writing - original

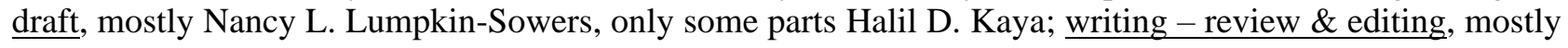
Nancy L. Lumpkin-Sowers, only some parts Halil D. Kaya.

\section{References}

1. Amin, M. (2010). Crime and Security in the Eastern Europe and Central Asia Region, World Bank Enterprise Note (15), World Bank. Available at: http://documents.worldbank.org/curated/en/655801468254089683/pdf/603420BRI0Crim10Box358317 B01PUBLIC1.pdf.

2. Árvai, Z., Karl D., and Otker-Robe, I. (2009). Regional Financial Interlinkages and Financial Contagion Within Europe, Financial Contagion, pp. 299-340. Available at: https://d1wqtxts1xzle7.cloudfront.net/41170698/Regional_Financial_Interlinkages_and_Fin2016011413233-1piqco8.pdf?1452841356=\&response-content- 
disposition=inline\%3B+filename\%3DRegional_Financial_Interlinkages_and_Fin.pdf \&Expires=159193 4555\&Signature=F2nvR1T wUXy8 Z4vfMQtQ5hCkG7aS4NGn5M zMgvzcmmbWhZb46QU5OMO bnDuu $\sim$ bd J12he665LPtXbjr 0ZRl 2EOMBVHQcVo7cJibf jDQpe1gHc $\sim$ gzTf2jbUA0aPIoZKvzjgR7 rnc0pJA9U7Y5fwXbfpEUdj6ztxURHMu5AJ0RyRjv6o2KdEAaSa90hG J1tCDSUshBGG1V8KjOIxjet 2qgX9xmxOxetrJmhgdgo vTCrzoHxC-

rRayUhcXvAjdIKNEI E2VKsgDWyRR61S2NT4yHu6M6oGQdiZzmTLEcMnaMss $\sim$ zrhHtREufO8vn $\sim$ 1dTNalLuKx2YwDxxhtQw \&Key-Pair-Id=APKAJLOHF5GGSLRBV4ZA.

3. Balas, A. N., and Kaya, H. D. (2019a). Economic Crisis and Security Concerns of Wholesalers in Eastern European and Central Asian Countries, Journal of Eastern European and Central Asian Research, 6(2), 245-258. Available at: https://ieeca.org/journal/index.php/JEECAR/article/view/262.

4. Balas, A. N., and Kaya, H. D., (2019b), The Global Economic Crisis And Retailers' Security Concerns: The Trends, SocioEconomic Challenges, 3(2), 5-14. doi: https://doi.org/10.21272/sec.3(2).5-14.2019.

5. Balwin, R. (2009). The Great Trade Collapse: Causes, Consequences, and Prospects, Centre for Economic Policy Research for VoxEU.org. Available at: https://books.google.com/books?hl=en\&lr=\&id=OsGokPMG5aIC\&oi=fnd\&pg=PR7\&dq=The+Great+T rade+Collapse:+Causes, + Consequences, + and+Prospects\&ots=1GjTxJKDEv\&sig=jddQOqauCR4GqrjJe yBVDVJmQj0\#v=onepage\&q=The\%20Great $\% 20$ Trade $\% 20$ Collapse $\% 3 \mathrm{~A} \% 20$ Causes $\% 2 \mathrm{C} \% 20 \mathrm{Consequ}$ ences\%2C\%20and\%20Prospects\&f $=$ false

6. Begg, B., Pickles, J. and Smith, A. (2003). Cutting it: European Integration, Trade Regimes, and the Reconfiguration of East-Central European Apparel Production, Environment and Planning A, 35(12), 2191-2207. Available at: https://journals.sagepub.com/doi/abs/10.1068/a35314.

7. Bourguignon, F. (2000). Crime, Violence and Inequitable Development, Edited by Boris Pleskovic and Joseph E. Stiglitz, Annual World Bank Conference on Development Economics 1999 (The World Bank), 199-220. Available at: http://documents.worldbank.org/curated/en/448681468741326292/pdf/multipage.pdf\#page $=205$.

8. Cattaneo, O., Gereffi, G., and Staritz, C. (2010). Global Value Chains in a Postcrisis World: Resilience, Consolidation, and Shifting End Marketz, In Global Value Chains in a Postcrisis World: A development Perspective, by Olivier Cattaneo, Gary Gereffi and Cornelia Staritz, pp. 3-20. Available at: https://books.google.com/books?hl=en\&lr=\&id=jiqaTSdjHfgC\&oi=fnd\&pg=PA3\&dq=Global+Value+ Chains+in+a+Postcrisis+World:+Resilience, + Consolidation, + and+Shifting+End+Marketz\&ots=QL8t0 XQVJD\&sig=L_UOJGdwrOIIfH2hDrCafLiH90c\#v=onepage\&q=Global\%20Value\%20Chains\%20in\% 20a\%20Postcrisis\%20World\%3A\%20Resilience\%2C\%20Consolidation\%2C\%20and $\% 20$ Shifting $\% 20 \mathrm{E}$ nd\%20Marketz\&f=false.

9. Cho, Y., and Newhouse, D. (2011). How Did the Great Recession Affect Different Types of Workers? Evidence from 17 Middle-Income Countries, The World Bank. Available at: https://www.econstor.eu/bitstream/10419/51767/1/668201754.pdf.

10. Claessens, S., Dell'Ariccia, G., Igan, D., and Laeven, L. (2010). Cross-Country Experiences and Policy Implications from the Global Financial Crisis. Economic Policy, 25(62), 267-293. Available at: https://academic.oup.com/economicpolicy/article-abstract/25/62/267/2918347.

11. Drahokoupil, J., and Myant, M., (2010). Varieties of Capitalism, Varieties of Vulnerabilities: Financial Crisis and its Impact on Welfare States in Eastern Europe and the Commonwealth of Independent States.

Historical Social Research/Historische Sozialforschung, 35(2), 266-295. Available at: https://www.ssoar.info/ssoar/bitstream/handle/document/31041/ssoar-hsr-2010-no_2_no_132drahokoupil_et_al-varieties_of_capitalism.pdf?sequence=1\&isAllowed=y\&lnkname=ssoar-hsr-2010no_2_no_132-drahokoupil_et_al-varieties_of_capitalism.pdf

12. Fishback, P. V., Johnson, R. S., and Kantor, S. (2010). Striking at the Roots of Crime: The Impact of Welfare Spending on Crime During the Great Depression. The Journal of Law and Economics, 53(4), 715-740. Available https://heinonline.org/HOL/Page?handle=hein.journals/jlecono53\&div=37\&g sent=1\&casa token=BMMM hHYrMDYAAAAA:ehociuZBQqMJ1EdgmIMnKhThwKiYk9j6KRg98S4idOFYj7BWX5mCnZ6yBiA6qyiNpSOB9T6wA\&collection=journals.

13. Gereffi, G., and Frederick, S. (2010). The Global Apparel Value Chain, Trade, and the Crisis: Challenges and Opportunities for Developing Countries, In Global Value Chains in a Postcrisis World: A Development Perspective, by Olivier Cattaneo, Gary Gereffi, Cornelia Staritz and Eds., pp. 157-208. 

Washington,
DC:
The
World
Bank.
Available
at: https://openknowledge.worldbank.org/bitstream/handle/10986/3769/WPS5281.pdf;sequence=1.

14. Halac, M., Schmukler, S. L., Fernández-Arias, E., and Panizza, U. (2004). Distributional Effects of Crises: the Financial Channel. Economia, 5(1), 1-67. Available at: https://www.jstor.org/stable/pdf/20065467.pdf?casa token=2Tn8-aB 1kAAAAA:DHpZHgXTyMJaD0uq4L1_N56FIhp_cIzKLo33DHD3rqq8Q7K25Rq3qCl1Xk_UQ6ywotZh5z2tMpweUS98ZtbEUo2e6shl2Bsw50_AUji30BoSJtROwY

15. Ivaschenko, O., Nivorozhkin, A., and Nivorozhkin, E. (2012). The role of economic crisis and social spending in explaining crime in Russia: Regional panel data analysis. Eastern European Economics. Eastern European Economics, 50(4), 21-41. Available at: https://www.jstor.org/stable/pdf/41719877.pdf?casa_token=9wGhzk3Qb68AAAAA:eFgxcamL1UG21gn V7USNUrYF5CI8qufWhsVWpiFxLK3PgHDyTCxbddl3mDgD2IK36Lv20vOuthoO_NWUwwwniy2ut ZgqKZw13kcPt3MMWc8GSH37A2k.

16. Lin, M., (2008). Does Unemployment increase Crime? Evidence from US Data 1974-2000, Journal of Human Resources, Vol. 43, no. 2, pp. 413-436. Available at: http://jhr.uwpress.org/content/43/2/413.short

17. Lokshin, M., and Ravallion, M., (2000). Welfare Impacts of the 1998 Financial Crisis in Russia and the Response of the Public Safety Net. Economics of Transition, 8(2), 269-295. Available at: https://onlinelibrary.wiley.com/doi/abs/10.1111/1468-0351.00045.

18. Malouche, M., (2009). Trade and Trade Finance Developments in 14 Developing Countries Post September 2008: A World Bank Survey. Policy Research Working Paper 5138, World Bank. Available at: http://documents.worldbank.org/curated/en/514711468313506103/pdf/WPS5138.pdf

19. Naudé, W., Surdej, A., and Cameron, M., (2019). The Past and Future of Manufacturing in Central and Eastern Europe: Ready for Industry 4.0? IZA Discussion Papers, No. 12141, Bonn: Institute of Labor Economics (IZA). Available at: https://www.econstor.eu/bitstream/10419/196639/1/dp12141.pdf

20. Pavlínek, P. (2015). The Impact of the 2008-2009 Crisis on the Automotive Industry: Global Trends and Firm-Level Effects in Central Europe. European Urban and Regional Studies, 22(1), 20-40. Available at: https://www.researchgate.net/profile/Petr_Pavlinek2/publication/260164730_The_impact_of_the_20082009_crisis_on_the_automotive_industry_Global_trends_and_firmlevel_effects_in_Central_Europe/links/0046352ff656fe0e79000000/The-impact-of-the-2008-2009crisis-on-the-automotive-industry-Global-trends-and-firm-level-effects-in-Central-Europe.pdf.

21. Pavlínek, P., and Ženka, J. (2010). The 2008-2009 Automotive Industry Crisis and Regional Unemployment in Central Europe. Cambridge Journal of Regions, Economy and Society, 3(3), $349-365$. Available at: http://www.secretariat.gerpisa.org/system/files/CJRES 2010 0.pdf.

22. Pickles, J., and Smith, A. (2011). Delocalization and Persistence in the European Clothing Industry: the Reconfiguration of Trade and Production Networks. Regional Studies, 45(2), 167-185. Available at: https://www.tandfonline.com/doi/full/10.1080/00343401003601933.

23. Ravallion, M. (2009). Bailing out the World's Poorest. Challenge, 52(2), 55-80. Available at: http://documents.worldbank.org/curated/en/869001468762586425/pdf/WPS4763.pdf.

24. Ravallion, M. (2001). Growth, Inequality and Poverty: Looking Beyond Averages. World Development, 29(11), 1803-1815. Available at: http://darp.lse.ac.uk/papersDB/Ravallion_(WorldDev_01).pdf.

25. Reinhart, C. M., and Rogoff, K. S. (2009). The Aftermath of Financial Crises. The American Economic Review, 99(2), 466-472. Available at: https://pubs.aeaweb.org/doi/pdf/10.1257/aer.99.2.466.

26. Sharma, S., and Winkler, H. (2017). The Labor Market Effects of Financial Crises: the Role of Temporary Contracts in Central and Western Europe, The World Bank. Available at: https://elibrary.worldbank.org/doi/abs/10.1596/1813-9450-8085.

27. Smith, A., and Swain, A. (2010). The Global Economic Crisis, Eastern Europe, and the Former Soviet Union: Models of Development and the Contradictions of Internationalization, Eurasian Geography and Economics, 51(1), 1-34. Available at: https://www.tandfonline.com/doi/abs/10.2747/1539-7216.51.1.1.

28. The World Bank. 2020. Enterprise Surveys: What Businesses Experience. Accessed May 2020. Available at: https://www.enterprisesurveys.org/en/enterprisesurveys. 